\title{
MODIFICATION OF THE ALUMINUM ALLOY BY THE RADIATION AND MECHANICAL TREATMENT
}

\author{
S.E. Donets, V.V. Lytvynenko, V.F. Klepikov, Yu.F. Lonin ${ }^{1}$, A.G. Ponomarev ${ }^{1}$, \\ S.Ye. Selivanov ${ }^{2}$, R.I. Starovoytov ${ }^{3}$, V.T. Uvarov ${ }^{1}$ \\ Institute of Electrophysics and Radiation Technologies NAS of Ukraine, Kharkiv, Ukraine; \\ ${ }^{I}$ NSC “Kharkov Institute of Physics and Technology”, Kharkiv, Ukraine; \\ ${ }^{2}$ Kherson State Maritime Academy, Kherson, Ukraine; \\ ${ }^{3}$ V.N. Karazin Kharkiv National University, Kharkiv, Ukraine
}

The paper discusses the problem of increasing the performance properties of aluminum alloy D16 for possible more efficient use in the fields of transport engineering. A property modification tool is a high current relativistic electron beam. The irradiation occurs in a vacuum. The peculiarities of the layer distribution of characteristic zones resulting from irradiation are investigated. Metallographic and fractographic analysis is carried out, and microhardness values are measured.

PACS: 07.05.Tp, 61.80.Fe, 81.70.-q, 87.63.Hg

\section{INTRODUCTION}

One of the modern ways of increasing the efficiency of materials use in the field of transport engineering is the use of aluminum alloys as facing, protective and loaded structural elements. This is due to their high enough ratio of strength to specific gravity, ductility, corrosion resistance, toughness value. Their most common use is in aircraft, for which a number of special alloys have been created [1, 2]. However, the use of aluminum-based alloys was of interest for the bus industry and for shipbuilding [3], in the latter case, the possibility of reducing the weight of structures compared to the use of steel, resistance to algae grow is particularly important. In turn, the variety of alloys is explained by the effort to create the most adapted material to the conditions of operational loads inherent in a particular product, which is usually achieved by the selection of the component composition of the alloy and its subsequent technological operations as rolling, heat treatment [4]. Current methods of producing alloys with improved properties include methods of intensive plastic deformation $[5,6]$, which consist of grinding and forcing the grains due to their extrusion at different angles through the die and torsion. A special place in obtaining materials with specified properties takes a direction that involves the creation of a combined structure with a defining role to the surface layers of the material. According to the concept [7], a deformable solid is a multilevel system in which the surface layer is a separate subsystem, which is simultaneously in a state of dynamic connection with the bulk of the material. Among the tools for modifying the surface layer itself, it is advisable to consider those that provide the thickness of the modified singing layer measured with the size of the zone of formation of new phases in the material, solid phase transformations. Among the modifiers, the use of intense electron beams seems to be promising, since they have a unique effect, which is that the maximum energy absorption falls on the subsurface layers located at a depth of about one third of the maximum immersion of the beam. In [8], we described the effect of increasing the elongation values before failure in mode over plastic deformation of an alloy D16 irradiated with a high-current relativistic electron beam (HCEB). The disadvantage of this method of treatment was that the surface of the sample was melted on it formed craters, it contained clear traces of uneven relief, which imposed certain restrictions on technological applications. We found that the effect of enhancement of plastic properties due to irradiation was achieved due to such effects as the grinding of grains and the formation of their predominant orientation. Remelting the material with an electron beam also led to the redistribution of alloying elements, which we established in [9] on the example of an aluminum alloy in 1933. Thus, the modified layer is really a separate subsystem, which is able to generate new properties of the material during its technological processing and further operation. The most appropriate way of eliminating the relief seems to us the use of hightemperature rolling, which to some extent is a partial implementation of the method described in [10], i. e. it is of interest to find out the features of two-stage material processing, which involves irradiation of HCEB with subsequent rolling.

\section{EXPERIMENTAL MATERIALS AND METHODS}

As a material for research we have selected one of the most common aluminum alloys D16, which is used in many fields of transport engineering, its elemental composition $(\mathrm{Al}, \quad 4.8 \% \mathrm{Cu}, \quad 1.5 \% \mathrm{Mg}, \quad 0.8 \% \mathrm{Mn}$, impurities $\mathrm{Fe}$ and $\mathrm{Si}$ no more $0.5 \%$ ). The irradiation was performed on an electron accelerator of the NSC "Kharkov Institute of Physics and Technology" TEMP-A with the following electron beam parameters: electron energy $350 \mathrm{keV}$, beam current $2 \mathrm{kA}$, pulse duration $5 \mu \mathrm{s}$, beam diameter $40 \mathrm{~mm}$. The vacuum in the beam drift chamber was $2 \cdot 10^{-5} \mathrm{~mm} \mathrm{Hg}$. The operation of placing and removing the samples from the irradiation zone was performed through a vacuum gateway. Rolling after irradiation was carried out at a temperature of $250 \mathrm{~K}$. The fractures of the samples were analyzed on a JEOL JSM-840 raster electron microscope. The microhardness was measured on a PMT-3 microhardness meter. X-ray structural analysis was performed on the DRON-4 installation. 


\section{DISCUSSION OF THE RESULTS}

The use of HCEB for the modification of aluminum alloy and the expectation of this type of processing of new technologically promising results is based on the mechanism of influence of the electron beam on the material. This effect is characterized by its complexity, which consists in the fact that the surface layer is melted down to the transition to the gas-plasma state and ablative emission of the substance occurs with partial subsequent condensation [11]. The deeper layers of the material undergo remelting, the subsequent ones fall into the thermal impact zone. The heating rates of cooling are $108 \mathrm{~K} / \mathrm{s}$. Such temperature gradients give rise to zones of expansion of compression in the depth of the target, which in some cases is manifested in a change in the value of the defect density [9] at depths much greater than the depth of penetration of the beam. This treatment mode also promotes the dispersion of saturation phases, which should improve the corrosion resistance. This assertion is based on the fact that, according to [3], the addition of alloying impurities such as $\mathrm{Zr}$ and $\mathrm{Cr}$ did not lead to an increase in corrosion resistance until heat treatment was applied. In addition to corrosion resistance for aluminum alloys, their ability to damp the impact loads is especially characteristic of the shipbuilding industry, since the features of maneuvering when entering ports under different conditions may be associated with impact loads. As we noted in [12], the complex mechanism acting on HCEB materials makes it possible to consider it as a means of obtaining shock-protective surfaces, since the modified layer has increased values of microhardness and thus a porous layer is formed between it and the main material due to shock-wave stresses $\sigma_{t}(r, t)$, which arising as a result of the thermoelastic effect [13]

$$
\sigma_{t}(r, t)=\Gamma \cdot \varepsilon(r, t),
$$

where $\varepsilon(r, t)$ is the density of absorbed radiation energy at the target; $r$ - the coordinate; $t$ - time; $\Gamma$ is the Grüneisen parameter of the substance. An additional component of stress formation is the recoil impulse generated by ablative emission [14]:

$$
\sigma=(\gamma-1) \cdot \omega,
$$

where $\gamma=1,2-$ the ratio of the specific values of the heat capacity of the solid and plasma; $\omega$ - volumetric density of radiation energy, $\mathrm{J} / \mathrm{cm}^{3}$.

This set of mechanical effects is imposed on the conditions of simultaneous movement of the melting front and subsequent crystallization, resulting in a certain anisotropy in the orientation of the grains. We have suggested in [15] that such anisotropy will facilitate the conversion of kinetic energy into its own internal deformation energy along a tangent direction to the surface. Such a deformation mechanism may develop due to the aforementioned increase in plasticity of the beam-modified layer and a higher value of microhardness. As can be seen from Fig. 1 the beammodified surface (top) is substantially different from the base irradiated layer. But the surface, which was not machined after irradiation, has a fractured structure (see Fig. 1,a), which is unacceptable from a technological point of view. After mechanical rolling (see Fig. 1,b), we observe the healing of pores and cracks due to rolling and sealing at elevated temperature.
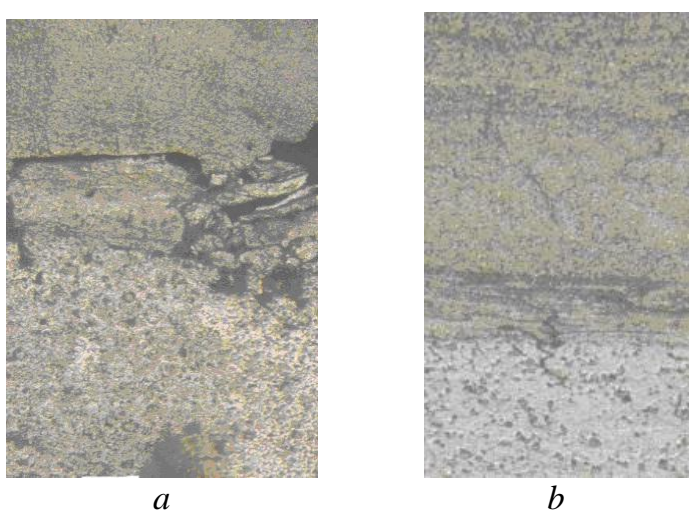

Fig. 1. Image of D16 alloys: after irradiation without rolling (a); rolling after irradiation (b). Increase $x 800$

In both cases, the values of the microhardness were measured in the areas known as the base region, the transition or interface region, the melting region and the condensed area [9]. The condensed area is the area from which ablation of the molten substance occurred, followed by back condensation. The melting region is characterized by crystallization occurring under acoustic vibrations. The values of microhardness are shown in Table. As we can see, modifying the action of the beam can cause a significant increase in microhardness, which is explained by the fragmentation of the grain structure, the accumulation in the middle of dislocation grains. More clearly it can be seen on the nature of the material breaking. For the interface region (indicated by a green arrow in Fig. 2), the smallest value of microhardness is evident, which is explained by the fact that it is transient and contains pores, while being able to act as the damper that distributes the field of shock mechanical stresses. The base region (indicated by a yellow arrow in Fig. 2) has a characteristic microhardness value with a slight increase in its value after rolling due to hardening. It is characterized by the viscous nature of the hack. The area of melting has significantly higher values of microhardness, its grains are perpendicular to the surface, and the fracture character is fragile and occurs outside the grain boundaries. The region of precondensation showed the highest indicators of microhardness (see Fig. 2 red arrow). It is characterized by a fragile break in the body of the grains.

The value of microhardness in region of the alloy sample

\begin{tabular}{|c|c|c|c|c|}
\hline Region & Bas & Int & Remelt & Recond \\
\hline $\begin{array}{c}\text { MicHard MPa } \\
\text { Before Rolling }\end{array}$ & 1180.4 & 931.1 & 1673.7 & 1819.1 \\
\hline $\begin{array}{c}\text { MicHard MPa } \\
\text { After Rolling }\end{array}$ & 1224.9 & 1102.3 & 1701.4 & 1968.9 \\
\hline
\end{tabular}

In our opinion, some increase of microhardness values after mechanical rolling should be due to the phenomenon of hardening, whose traces are well traced on the fractogram. 


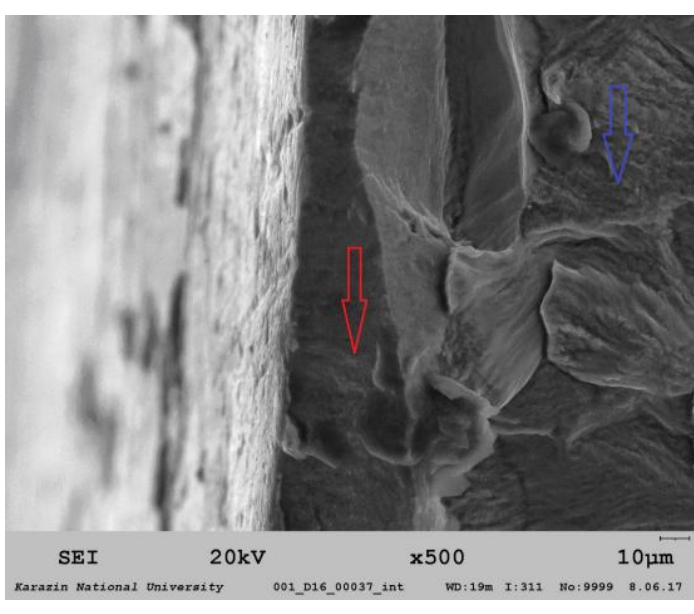

$a$

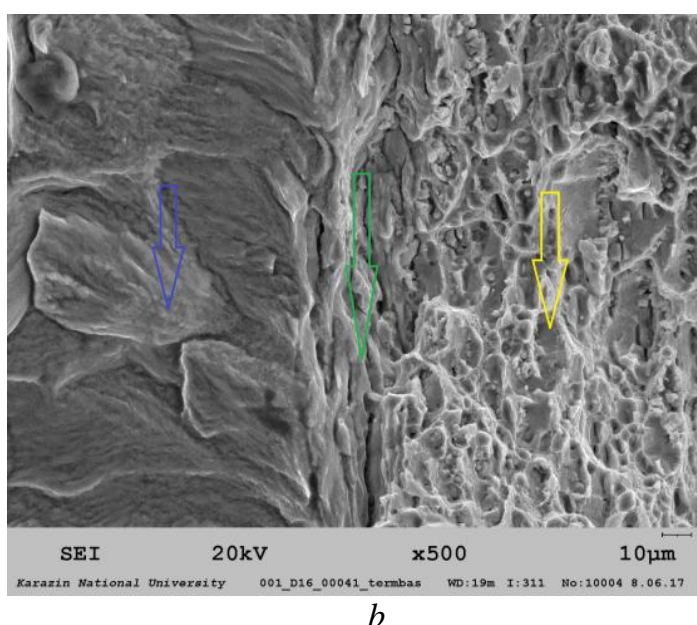

Fig. 2. Fractograms of the fracture of the sample after radiation mechanical treatment

The effects of increasing microhardness are probably also due to the redistribution of alloying elements and the formation of new phases. In the untreated sample, only aluminum lines were detected by X-ray diffraction analysis (Fig. 3,a). Whereas on the modified surface two lines are identified which correspond to the copper compounds of Fig. 3,b. There is also a slight increase in the aluminum lattice parameter, which may indicate the formation of a solid replacement solution. The main difference between the modified surface is the narrowing of the half-widths of the lines, which can be explained by the improvement of the structure due to the thermal effect of the energy release of internal stresses, which is formed due to irradiation [16] and the action of pulses of high pressure.

Consequently, in addition to microhardness values, the resulting effects of such treatment make it possible to expect, for example, increased tribological characteristics, since the thermal action of other concentrated energy flows [17] allows to improve the wear resistance of friction elements. In the mode of such material processing, more intensive redistribution of copper and aluminum compounds can be expected, since the material is in a non-equilibrium metastable state for some time when the solubility of these elements increases [18]. Bringing the observed effects to technological implementation requires a number of technical solutions. Because the irradiation occurs in a vacuum, it is necessary to create a vacuum gateway to feed material into the treatment area. Another problem is that the generation of pulses of electron radiation is accompanied by the output of the brake radiation. Radiation-resistant detectors based on mercury compounds can be used to control it [19, 20]. Metalpolymeric materials can be used to protect measuring devices and electronics [21, 22].
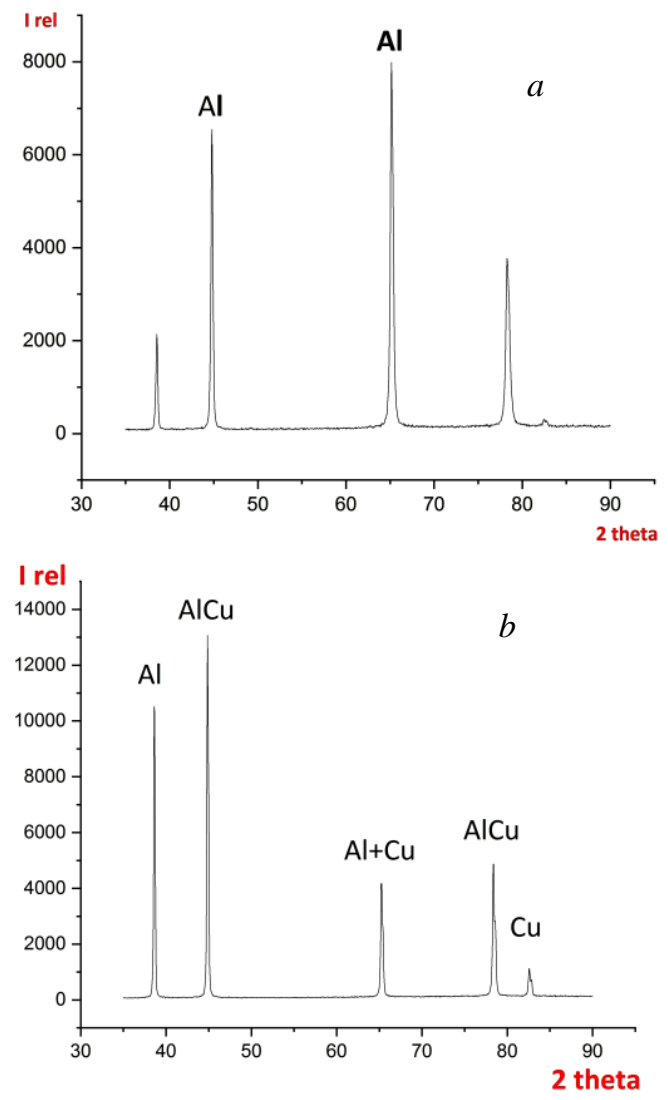

Fig. 3. Results of X-ray diffraction analysis of samples: initial sample (a); modified sample (b)

\section{CONCLUSION}

An approach to modifying the surface properties of an aluminum alloy by treating a HCEE with subsequent mechanical rolling at elevated temperature is proposed in the work, which eliminates the lack of surface roughness due to irradiation. This is one of the deterrents against the use of these beams for applied purposes, since obtaining a modified layer in metals at a depth of $100 \ldots 300 \mu \mathrm{m}$ seems very promising. With respect to aluminum alloys, mechanical rolling has the important function of compacting the material and rolling up pores and cracks, which allows to obtain a technologically suitable surface with improved performance properties.

\section{ACKNOWLEDGEMENT}

The research presented in this article was conducted by financial support of the state budget program "Support for the development the priority areas of scientific researches" (Budget Financial Code 6541230). 


\section{REFERENCES}

1. Red. Ye.N. Kablova. Istoriya aviatsionnogo materialovedeniya: VIAM-75 let poiska, tvorchestva, otkrytiy. M.: "Nauka", 2007, 343 p. (in Russian).

2. I.N. Fridlyander. Alyuminiyevyye splavy v aviaraketnoy i yadernoy tekhnike // Vestnik RAN. 2004, v. 74, N 12, p. 1076-1081 (in Russian).

3. W. Jurczak. Study of the corrosion resistence of ship aluminum alloys // Scientific Journal of Polish Naval Academy. 2016 (LVII), N 3(206), p. 37-65.

4. B.I. Bondarev, V.I. Napalkov, V.I. Tararyshkin. Modifitsirovaniye alyuminiyevykh splavov. M.: "Metallurgiya", 1979, 223 p. (in Russian).

5. R.Z. Valiyev. Nanostrukturnyye materialy, poluchennyye intensivnoy plasticheskoy deformatsiyey. M.: "Logos", 2000, 272 p. (in Russian).

6. B. Rakhadilov, G. Uazyrkhanova, A. Myakinin, Z. Uazyrkhanova. Effect of Intensive Plastic Deformation on Microstructure and Mechanical Properties of Aluminum Alloys // IOP Conf. Series: Materials Science and Engineering. 2016, v. 142, p. 012035 .

7. V.E. Panin, A.V. Panin. Effect of the surface layer in a solid under deformation // Physical Mezomechanics. 2005, v. 8, N 5, p. 7-15.

8. V.V. Bryukhovetskij, V.V. Litvinenko, V.F. Klepikov, R.I. Kuznetsova, V.F. Kivshik, V.P. Pojda, V.T. Uvarov. Effect of the pulsed electron irradiation on superplasticity properties of duraluminium // Fizika $i$ khimiya obrabotki materialov. 2002, v. 4, p. 33-38 (in Russian).

9. A.G. Kobets, P.R. Horodek, Yu.F. Lonin, V.V. Lytvynenko, A.G. Ponomarev, O.A. Startsev, V.T. Uvarov. Melting effect on high current electron beam on aluminum alloy 1933 // Surface Engineering and Applied Electrochemistry. 2015, v. 51, N 5, p. 478482.

10. T. Hausol, H.W. Hoppel, M. Goken. Microstructure and mechanical properties of accumulative roll bonded aluminum alloy AA5754 // Journal of Physics: Conference Series. 2010, v. 240, p. 21-28.

11. V.F. Klepikov, V.V. Lytvynenkoo, Yu.F. Lonin, et al. The dynamics of the gas - plasma torch formed by the high current beam action on solid state targets // Problems of Atomic Science and Technology. Series “Plasma Physics" (15). 2009, N 1(59), p. 119 121.

12. V.I. Boyko, A.N. Valyayev, A.D. Pogrebnyak. Modifikatsiya metallicheskikh materialov impul'snymi moshchnymi puchkami chastits // UFN. 1999, v. 169, N 11, p. 1243-1271.

13. V.D. Volovik, V.T. Lazurik-El'tsufin. Akusticheskiy effekt puchkov zaryazhennykh chastits V metallakh // Fizika tverdogo tela. 1973, v. 15(8), p. 2305-2307 (in Russian).

14. S.S. Batsanov, B.A. Demidov, L.I. Rudakov. Ispol'zovaniye sil'notochnogo REP dlya osushchestvleniya strukturnykh prevrashcheniy // Pis'ma v ZHETF. 1979, v. 30(9), p. 611-613 (in Russian).

15. M.I. Bazaleev et al. Aluminum alloys shock protective surface modified by the high current electron beam // Journal of Surface Physics and Engineering. 2017, v. 2, N 1, p. 38-43.

16. V.T. Uvarov et al. Radiation acoustic control over the thermal parameter of construction materials irradiated by intense relativistic electron beam // Phys. of Part. and Nucl. Latter. 2014, v. 11, N 3, p. 274-281.

17. B. Antoszewski, V. Tarelnik. Laser texturing of sliding surfaces of bearings and pump seals // Applied Mechanics and Materials. 2014, v. 630, p. 301-307.

18. S.E. Donets et al. Aluminum surface coating of copper using high-current electron beam // Problems of Atomic Science and Technology. Series "Plasma Electronics and New Methods of Acceleration" (9). 2015, N 4(98), p. 302-305.

19. A.A. Zaharchenko, A.I. Skrypnyk, M.A. Khazhmuradov, E.M. Prohorenko, V.F. Klepikov, V.V. Lytvynenko. Simulation of characteristics of gamma-radiation detectors based on mercury compounds // Problems of Atomic Science and Technology. Series "Nuclear Physics Investigations" (60). 2013, N 3(85), p. 231-235.

20. Priyanthi M. Amarasinghe et al. Growth of high quality mercurous halide single crystals by physical vapor transport method for AOM and radiation detection applications // Journal of Crystal Growth. 2016, v. 450, p. 96-102.

21. E.M. Prokhorenko et al. Metal containing composition materials for radiation protection // Problems of Atomic Science and Technology. Series "Physics of Radiation Effect and Radiation Materials Sciences". 2014, N 4(92), p. 125-129.

22. E.M. Prokhorenko et al. Improvement of characteristics of composite materials for radiation biological protection // Problems of Atomic Science and Technology. Series "Nuclear Physics Investigations" (61). 2013, N 6(88), p. 240-243. 


\title{
МОДИФИКАЦИЯ АЛЮМИНИЕВОГО СПЛАВА РАДИАЦИОННОЙ И МЕХАНИЧЕСКОЙ ОБРАБОТКАМИ
}

\author{
С.Е. Донец, В.В. Литвиненко, В.Ф. Клепиков, Ю.Ф. Лонин, А.Г. Пономарёв, С.Е. Селиванов, \\ Р.И. Старовойтов, В.Т. Уваров
}

Рассматриваются вопросы повышения эксплуатационных свойств алюминиевого сплава Д16 для возможного более эффективного применения в отраслях транспортного машиностроения. Инструментом модификации свойств является сильноточный релятивистский электронный пучок. Облучение происходит в вакууме. Выясняются особенности послойного распределения характерных зон, возникающих в результате облучения. Осуществляются металлографический и фрактографический анализы, проводится измерение значений микротвердости.

\section{МОДИФІКАЦІЯ АЛЮМІНІЕВОГО СПЛАВУ РАДІАЦЙНОЮ ТА МЕХАНІЧНОЮ ОБРОБКАМИ}

\author{
С.С. Донець, В.В. Литвиненко, В.Ф. Клепіков, Ю.Ф. Лонін, А.Г. Пономарьов, С.С. Селіванов, \\ P.І. Старовойтов, В.Т. Уваров
}

Розглядаються питання підвищення експлуатаційних властивостей алюмінісвого сплаву Д16 для можливого більш ефективного застосування в галузях транспортного машинобудування. Інструментом модифікації властивостей $\epsilon$ сильнострумовий релятивістський електронний пучок. Опромінювання відбувається у вакуумі. 3'ясовуються особливості пошарового розподілу характерних зон, які виникають внаслідок опромінення. Здійснюються металографічний та фрактографічний аналізи, проводиться вимірювання значень мікротвердості. 